\title{
Relationship between First Values of Red Cell Distribution Width, Mean Platelet Volume, Platelet Distribution Width, and Hospital Mortality in Acute Deep Venous Thrombosis
}

\author{
Sonay Oğuz \\ Department of Cardiovascular Surgery, Canakkale Onsekiz Mart University, Canakkale, Turkey
}

\begin{abstract}
Objective: To determine the relationship between red cell distribution width (RDW), mean platelet volume (MPV), platelet distribution width (PDW) values and mortality in acute deep vein thrombosis (DVT).

Study Design: Descriptive study.

Place and Duration of Study: Canakkale Onsekiz Mart University Health Practice and Research Hospital, Turkey, from 2015 to 2020 .

Methodology: Hospitalised cases of acute DVT were detected. Discharged patients (externe group -EG), mortal course (mortality group - MG) and control group ( healthy persons without thrombosis - CG) were formed. Statistical significance of the first values of RDW, MPV and PDW between groups was evaluated. In addition, the difference between the groups was evaluated according to the age, gender, platelet count, and level of the thrombosis (proximal, distal).

Results: There was a significant increase in RDW values between CG and EG (13.63 \pm 1.37 vs. $15.97 \pm 3.20 ; p=0.012), C G$ and MG (13.63 \pm 1.37 vs. $17.85 \pm 3.73 ; p=0.003)$. There was a significant increase in PDW values between CG and MG (16.78 \pm 0.41 vs. $18.05 \pm 1.07 ; p<0.001)$ and between EG and MG $(16.98 \pm 0.51$ vs. $18.05 \pm 1.07 ; p<0.001)$. There was no significant difference in other variables.

Conclusion: The results show that increased RDW values may be associated with deep venous thrombosis; and increased PDW values may be associated with mortality. Following RDW and PDW values, which are fast, inexpensive and widely available, can be useful as an early predictor of thrombosis and poor prognosis.
\end{abstract}

Key Words: Red cell distribution width, Mean platelet volume, Platelet distribution width, Deep venous thrombosis, Predictor, Mortality, Poor prognosis.

How to cite this article: Oğuz S. Relationship between First Values of Red Cell Distribution Width, Mean Platelet Volume, Platelet Distribution Width, and Hospital Mortality in Acute Deep Venous Thrombosis. J Coll Physicians Surg Pak 2021; 31(04):379-382.

\section{INTRODUCTION}

Deep venous thrombosis (DVT) is seen worldwide an incidence of 1-2, and it can have a mortality rate of 10-30\% with the development of venous thromboembolism. ${ }^{1}$ Important factors in its fatality are related to thrombus burden, circulatory problems and embolic events caused by the extremity involved. ${ }^{2,3}$ Early diagnosis and treatment are important in DVT as well as in every disease. Although treatment methods are determined with certain standards, markers that can be an early predictor in terms of complications may provide advantages in terms of rapid intervention, effective treatmentand survival.

Correspondence to: Dr. Sonay Oğuz, Department of Cardiovascular Surgery, Canakkale Onsekiz Mart University, Canakkale, Turkey

E-mail:soguz@comu.edu.tr

Received: January 19, 2021; Revised: February 13, 2021;

Accepted: March 05, 2021

DOI: https://doi.org/10.29271/jcpsp.2021.04.379
DVT is expected to cause more severe disorders by affecting the wider segment in relation to the high thrombus burden occurring in the venous area. Thrombocytes and erythrocytes are effective cellular elements in thrombus formation. Its effects on the formation and increase of thrombus are known. Fibrin and erythrocyte load is high in thrombosis of the venous system. ${ }^{4}$ Parallel to this, changes in the mean red cell distribution width (RDW), platelet volume (MPV) and platelet distribution width (PDW) values may occur with the amount of clot formed and consumed erythrocyte, platelet amount. These changes can be used as indicators of disease course, treatment efficiency and prognosis. ${ }^{5,6}$ However, this situation is still not clear enough. These biomarkers can potentially predict mortal complications, and be a candidate to be used as a prognostic marker in the presence of a strong relationship. In this study, the aim was to find out whether there is a significance between the initial RDW, MPV, PDW values and mortality in hospitalised acute DVT patients.

\section{METHODOLOGY}

Acute DVT cases, who were hospitalised in Çanakkale Onsekiz Mart University Health Practice and Research Hospital between 
2015 and 2020, were detected. Discharged cases (externe group, EG), mortal course (mortality group, MG) and control group (healthy persons without thrombosis, CG) were formed. Statistical significance of the first values of RDW, MPV and PDW between groups was evaluated. In addition, the difference between the groups was evaluated according to the age, gender, platelet count, and thrombosis level of the patients (proximal, distal). Local ethics committee approval obtained for the study.

Statistical analyses were conducted using SPSS, version 23.0 (IBM, Chicago, IL) software. Categorical variables were given as number $(n)$ and percentage(\%). The comparison b/w categorical variables were made by using Chi-square test and Fisher's Exact test. Continuous variables were defined as the mean and standard deviation. The suitability of variables to normal distribution was examined using histograms and the Shapiro-Wilk test. The differences between the groups were evaluated with the one-way ANOVA test, and the in-group comparisons were made using the post-hoc Tukey's test after analysing the homogeneity of the variances with the Levene test. P values less than 0.05 were considered significant.

\section{RESULTS}

Eight cases in the mortality group (MG), 43 cases in the discharge group (EG), 19 cases in the control group (CG) were included in the study. All data are shown in Table I. There were significant differences in RDW values between CG and EG ( $p=$ $0.012)$ and between CG and MG ( $p=0.003)$. There were significant difference in PDW values between CG and MG $(p<0.001)$ and between EG and MG ( $p<0.001$ ). There was no significant difference in other variables.

Mortality was due to pulmonary embolism detected by CT in two cases, severe lung infection in three cases, and cerebrovascular disease, acute renal and respiratory failure, and mesenteric ischemia in one case each.

\section{DISCUSSION}

In this study, it was aimed to find the correlation of initial values of RDW, MPV, PDW with mortality in acute DVT patients treated in this hospital. Since, mortality was associated with hospital, the hospitalised patients were included in the study. In current guidelines, it is recommended to arrange outpatient treatment without hospitalisation as much as possible in the treatment of DVT. Therefore, a small number of cases could be included in the study, even though the data were collected for the previous five years. In addition, DVT might have been recorded as a pre-diagnosis or misdiagnosis in the cases. Therefore, hospital consultations, epicrisis, discharge notes and doppler ultrasound reports of all cases were examined in detail; and it was made sure that cases had acute DVT without pulmoner thromboembolism.

RDW is a widely used laboratory parameter to measure the degree of erythrocyte anisocytosis, which reflects the variability in the size of circulating erythrocytes. ${ }^{7}$ There was a signifi- cant difference in RDW values between CG - EG ( $p=0.012), C G$ - MG $(p=0.003)$. This indicated that patients with acute DVT had an increased RDW value when they first came to the hospital. Same relationship has been shown in many studies. ${ }^{8-14}$ In this study, we obtained similar results related to RDW.

The reason for the rise of RDW value in venous thrombosis is not clearly understood. Some mechanical etiologies have been suggested: first, a subtle anemia can emerge in these cases; second, neurohormonal axis can create red blood cell generation; and finally, inflammation and associated cytokines might induce erythropoiesis. ${ }^{15}$ Greater change in red blood cell amounts indicating increased RDW has been linked with decreased red blood cell deformability, which might impair blood flow through the vessels. The resultant stasis may help explain elevated local blood viscosity. ${ }^{16}$ It has been shown that an increase in local blood viscosity, which is caused by red blood cell aggregation, decreases blood flow and results in triggering the generation of thrombosis through promoting collisions, vessel wall adhesion, and activation and adhesion of platelets. $^{17-19}$

In a previous study, it was shown that high MPV raises the risk of unprovoked venous thromboembolism independently. ${ }^{20}$ However, in the present study, a significant relationship between the groups in MPV values $(p>0.05)$ could not be found. This situation may be related to citrate or EDTA buffering, the time elapsed related to the analysis and their variation according to their standardization, as stated by Beyan. $^{21}$

PDW measures the variability in platelet size and is another marker of platelet activation. ${ }^{22}$ In this study, a significant difference was found between MG - CG (P<0.05) and MG - EG ( $p$ $<0.05$ ) in PDW values. In previous studies, it has been shown that PDW may be more effective than MPV in tracking platelet activation. ${ }^{22,23}$ Sevuk et al. demonstrated the predictive value of serial PDW follow-up in DVT patients for pulmonary thromboembolism. ${ }^{24}$ This study supports this and the results obtained that may be associated with mortality. Patients who were diagnosed with pulmonary thromboembolism (PTE) at the first admission to the hospital were not included in this study. Only cases diagnosed with acute DVT were included in the study. DVT and PTE can be seen together frequently. Sometimes, PTE cannot be diagnosed due to its subclinical course. In this study, pulmonary embolism was detected by CT examination in two patients (MG) because clinical complaints began after hospitalisation. The other three patients exitus with pulmonary complications. The mortal course of the patients in this study may be related to possible existing pulmonary embolism at their first visit, but it cannot be clarified this completely. Zhang et al. was able to show the relationship between the poor prognosis of laryngeal cancer and PDW values in their study. ${ }^{25}$ Close following PDW values in DVT patients, can be beneficial for early detection of both pulmonary embolism and poorprognosis. 
Table I: Variables in the groups and their statistical significance.

\begin{tabular}{|c|c|c|c|c|c|c|c|}
\hline & \multicolumn{2}{|c|}{ Control Group (CG) n:19 } & \multicolumn{2}{|c|}{ Externe Group (EG) n:43 } & \multicolumn{2}{|c|}{ Mortal Group (MG) n:8 } & $\left.\mathbf{P}^{*}, \#\right)$ \\
\hline $\begin{array}{l}\text { Age (years) } \\
\text { mean } \pm \text { S.D }\end{array}$ & \multicolumn{2}{|c|}{$61.05 \pm 22.32$} & \multicolumn{2}{|c|}{$59.42 \pm 17.79$} & \multicolumn{2}{|c|}{$76.38 \pm 14.54$} & $0.071^{*}$ \\
\hline $\begin{array}{l}\text { Gender n (\%) } \\
\text { (female / male) }\end{array}$ & \multicolumn{2}{|c|}{$9(47.4) / 10(52.6)$} & \multicolumn{2}{|c|}{$21(48.8) / 22(51.2)$} & \multicolumn{2}{|c|}{$4(50) / 4(50)$} & $0.991^{\#}$ \\
\hline $\begin{array}{l}\text { Platelet count } \\
\text { Mean } \pm \text { S.D }\end{array}$ & \multicolumn{2}{|c|}{$233.58 \pm 48.39$} & \multicolumn{2}{|c|}{$254.86 \pm 126.98$} & \multicolumn{2}{|c|}{$212.75 \pm 97.99$} & $0.532^{*}$ \\
\hline $\begin{array}{l}\text { Trombous Level } \\
\mathrm{n}(\%) \\
\text { (proximal / distal ) }\end{array}$ & & & \multicolumn{2}{|c|}{$18(72) / 7(28)$} & \multicolumn{2}{|c|}{$3(75) / 1(25)$} & $>0.999^{\wedge}$ \\
\hline \multirow[b]{2}{*}{$\begin{array}{l}\text { RDW } \\
\text { Mean } \pm \text { S.D }\end{array}$} & \multicolumn{2}{|c|}{$13.63 \pm 1.37$} & \multicolumn{2}{|c|}{$15.97 \pm 3.20$} & \multicolumn{2}{|c|}{$17.85 \pm 3.73$} & $0.002 *$ \\
\hline & $\begin{array}{l}\text { CG - EG } \\
P=0.012\end{array}$ & $\begin{array}{l}\text { CG - MG } \\
P=0.003\end{array}$ & $\begin{array}{l}E G-C G \\
P=0.012\end{array}$ & $\begin{array}{l}E G-M G \\
P=0.218\end{array}$ & $\begin{array}{l}\text { MG - CG } \\
P=0.003\end{array}$ & $\begin{array}{l}\text { MG - EG } \\
P=0.218\end{array}$ & \\
\hline $\begin{array}{l}\text { MPV } \\
\text { Mean } \pm \text { S.D }\end{array}$ & \multicolumn{2}{|c|}{$8.46 \pm 1.04$} & \multicolumn{2}{|c|}{$8.27 \pm 1.29$} & \multicolumn{2}{|c|}{$8.18 \pm 1.23$} & $0.810^{*}$ \\
\hline \multirow{2}{*}{$\begin{array}{l}\text { PDW } \\
\text { Mean } \pm \text { S.D }\end{array}$} & \multicolumn{2}{|c|}{$16.78 \pm 0.41$} & \multicolumn{2}{|c|}{$16.98 \pm 0.51$} & \multicolumn{2}{|c|}{$18.05 \pm 1.07$} & $<0.001^{*}$ \\
\hline & $\begin{array}{l}E G \\
P=0.511\end{array}$ & $\begin{array}{l}\text { MG } \\
p<0.001\end{array}$ & $\begin{array}{l}\text { CG } \\
p=0.511\end{array}$ & $\begin{array}{l}\text { MG } \\
p<0.001\end{array}$ & $\begin{array}{l}\text { CG } \\
p<0.001\end{array}$ & $\begin{array}{l}\text { EG } \\
p<0.001\end{array}$ & \\
\hline
\end{tabular}

MPV: Mean platelet volume. RDW: Red cell distribution width. PDW: Platelet Distribution Width. $p^{*}$ : One way ANOVA. P: Post-hoc Tukey's test. $p^{*}$ : Chi-square test. $p^{\wedge}$ : Fisher's Exact test

\section{CONCLUSION}

The results show that incresed RDW values may be associated with deep venous thrombosis and incresed PDW values may be associated with mortality. The RDW and PDW values, which are fast, inexpensive and widely available, can be useful as an early predictor of trombosis and poor prognosis.

\section{ETHICAL APPROVAL:}

This study was conducted in compliance with the ethical principles according to the Declaration of Helsinki, and it was approved by the local Institutional Review Board.

\section{PATIENTS' CONSENT:}

As this study was retrospective, the patients' consent was waived.

\section{CONFLICT OF INTEREST:}

The author declared no conflict of interest.

\section{AUTHOR'S CONTRIBUTION:}

SO: Contributions to conception and design, acquisition of data, interpretation of data, drafting of manuscript, reviewing the paper, advices, and final approval.

\section{REFERENCES}

1. Beckman MG, Hooper WC, Critchley SE, Ortel TL. Venous thromboembolism: a public health concern. Am J Prev Med 2010; 38(4):495-501. doi: 10.1016/j.amepre.2009.12.017

2. White RH. (2003). The epidemiology of venous thromboembolism. Circulation 2003; 107:I-4. doi: 10.1161/01.CIR. 0000078468.11849.66.

3. Husain SJ, Zubairi ABS, Fatima K, Irfan M, Atif M, Saeed MA. Clinical characteristics, management and outcome of major pulmonary embolism: an experience from a tertiary care center in Pakistan. J Pak Med Assoc 2009; 59(6):372-5.

4. Litvinov RI, Weisel JW. What is the biological and clinical relevance of fibrin? Semin Thromb Hemost 2016; 42(4): 333-43. doi: $10.1055 / \mathrm{s}-0036-1571342$.
5. Koupenova M, Kehrel BE, Corkrey HA, Freedman JE. Thrombosis and platelets: an update. Eur Heart J 2017; 38(11):785-91. doi: 10.1093/eurheartj/ehw550.

6. Sengul S, Guler Y, Calis H, Karabulut Z. The Role of Serum Laboratory Biomarkers for Complicated and Uncomplicated Appendicitis in Adolescents. J Coll Physicians Surg Pak 2020; 30(4): 420-4. doi: 10.29271/jcpsp.2020.04.420

7. Yüksel C, Erşen O, Culcu S, Bakırarar B, Unal AE, Demirci S. Prognostic role of red distribution width (RDW) value in gastric cancer. J Coll Physicians Surg Pak 2021; 31(1): 21-6. doi: 10.29271/jcpsp.2021.01.21.

8. Hammons L, Filopei J, Steiger D, Bondarsky E. A narrative review of red blood cell distribution width as a marker for pulmonary embolism. J Thromb Thrombolysis 2019; 48(4):638-647. doi: 10.1007/s11239-019-01906-w.

9. Lippi G, Buonocore R, Cervellin G. Value of red blood cell distribution width on emergency department admission in patients with venous thrombosis. Am J Cardiol 2016; 117(4):670-5. doi: 10.1016/j.amjcard.2015.11.024

10. Maino A, Abbattista M, Bucciarelli P, Artoni A, Passamonti SM, Lanfranconi S, et al. Red cell distribution width and the risk of cerebral vein thrombosis: a case-control study. Eur J Intern Med 2017; 38:46-51. doi: 10.1016/j.ejim.2016. 10.017 .

11. Zhou XY, Chen HL, Ni SS. Red cell distribution width in predicting 30-day mortality in patients with pulmonary embolism. J Crit Care2017; 37:197-201. doi: 10.1016/j.jcrc. 2016.09.024

12. Begum S, Rumana N, Devi RM, Sadananda KS, Bharathi M. Hematological parameters in cardiovascular diseases. Pak J Physiol 2018; 14(1): 23-6.

13. Sahin M, Emektar E, Kılıç NA, Ozturk D. Bulus H. The role of platelet parameters in thrombosed hemorrhoids. J Coloproctol 2020; 40(4):362-7. doi: 10.1016/j.jcol. 2020.07.002..

14. Sincer I, Mansiroglu AK, Aktas G, Gunes Y, Kocak MZ. Association between Hemogram Parameters and Coronary Collateral Development in Subjects with Non-ST-Elevation Myocardial Infarction. Rev Assoc Med Bras 2020; 66(4):160-5. doi: 10.1590/1806-9282.66.2.160 
15. Alt E, Banyai S, Banyai M, Koppensteiner R. Blood rheology in deep venous thrombosis: relation to persistent and transient risk factors. Thromb Res 2002; 107(3-4):101-7. doi: 10.1016/S0049-3848(02)00302-X.

16. Patel KV, Mohanty JG, Kanapuru B, Hesdorffer C, Ershler WB, Rifkind JM. Association of the red cell distribution width with red blood cell deformability. Adv Exp Med Biol 2013; 765:211-6. doi: 10.1007/978-1-4614-4989-8_29.

17. Yu FT, Armstrong JK, Tripette J, Meiselman HJ, Cloutier G. A local increase in red blood cell aggregation can trigger deep vein thrombosis: evidence based on quantitative cellular ultrasound imaging. J Thromb Haemost 2011; 9(3): 481-488. doi: 10.1111/j.1538-7836.2010.04164.x.

18. Hathcock JJ. Flow effects on coagulation and thrombosis. Arterioscler Thromb Vasc Biol 2006; 26(8):1729-37. doi: 10.1161/01.ATV.0000229658.76797.30.

19. Nash GB, Watts T, Thornton C, Barigou M. Red cell aggregation as a factor influencing margination and adhesion of leukocytes and platelets. Clin Hemorheol Microcirc 2008; 39(1-4):303-10. doi: 10.3233/CH- 2008-1109.

20. Braekkan SK, Mathiesen EB, Njolstad I, Wilsgaard T, Stormer J, Hansen JB. Mean platelet volume is a risk factor for venous thromboembolism-the Tromso study. J Thromb Haemost
2009; 8(1):157-62. doi: 10.1111/j.1538-7836. 2009.03498.x.

21. Beyan C. Is mean platelet volume a predictive marker in patients with venous thrombosis? Clin Appl Thromb Hemost 2012; 18(6):670-671. 10.1177/1076029612452780

22. Orak M, Karakoç $Y$, Üstündag $M$, Yildirim $Y$, Celen $M K$, Güloglu C. An investigation of the effects of the mean platelet volume, platelet distribution width, platelet/ lymphocyte ratio, and platelet counts on mortality in patents with sepsis who applied to the emergency department. Niger J Clin Pract 2018; 21(5):667-671. doi: 10.4103/njcp.njcp_44_17.

23. Beyazyildiz E, Citirik M, Simsek M, Beyazyildiz O, Haznedaroglu IC. Branch retinal vein occlusion associated with platelet activation. Turk J Med Sci 2019; 49(1):283-7. doi:10.3906/sag-1807-223.

24. Sevuk U, Bahadir MV, Altindag R, Baysal E, Yaylak B, Ay N. Value of serial platelet indices measurements for the prediction of pulmonary embolism in patients with deep venous thrombosis. Ther Clin Risk Manag 2015; 11:1243. doi: $10.2147 /$ TCRM.S89355.

25. Zhang H, Liu L, Fu S, Liu YS, Wang C, Liu T, et al. Higher platelet distribution width predicts poor prognosis in laryngeal cancer. Oncotarget 2017; 8(29),48138. doi: 10.18632/oncotarget.18306. 